\title{
Nutrient Composition, Metabolites and Microbial Counts in Litter Material of Broiler Chicken Fed Condensed Tannins Containing Guava Leaf Meal Supplemented Diets: Reduce Environmental Pollution and Alternate Feedstuffs for Ruminants
}

\author{
Vivek Saharan ${ }^{1}$, A.K. Pathak ${ }^{1 *}$, Neelesh Sharma ${ }^{2}$, R.K. Sharma ${ }^{1}$ and Himalaya Kumar ${ }^{1}$ \\ ${ }^{1}$ Division of Animal Nutrition, Faculty of Veterinary Sciences $\mathcal{E}$ A.H., Sher-e-Kashmir University of Agricultural Sciences and \\ Technology of Jammu, R.S. Pura, (J \& K), INDIA \\ ${ }^{2}$ Division of Veterinary Medicine, Faculty of Veterinary Sciences $\mathcal{E}$ A.H., Sher-e-Kashmir University of Agricultural Sciences and \\ Technology of Jammu, R.S. Pura, (J E K), INDIA \\ *Corresponding author: AK Pathak; E-mail: dranand_pathak@yahoo.com
}

Received: 12 April, 2020

Revised: 28 May, 2020

Accepted: 02 June, 2020

\begin{abstract}
Present study was conducted in 240 day-old broiler chicks to assess the effect of condensed tannins (CT) containing guava leaf meal (GLM) supplemented diet on nutrient composition, litter metabolites viz. $\mathrm{pH}$, moisture and ammonia concentration) and microbial counts after completion of feeding trial of 42 days. Chicks were randomly allocated into 4 dietary treatments, with 4 replicates of 15 chicks in each pen in a completely randomized block design (CRD). Chicks were fed basal diets supplemented with GLM@1.5, 2.5 and 3.5 percent, in $\mathrm{T}_{1}, \mathrm{~T}_{2}$ and $\mathrm{T}_{3}$ groups, respectively, while, $\mathrm{T}_{0}$ group fed only basal diet. Litter materials of chicks showed good nutrient profiles and properly sterilized litter material act as alternative feed ingredient for ruminants feed. Supplementation of GLM in the diets of chicks significantly $(\mathrm{P}<0.05)$ reduced moisture, $\mathrm{pH}, \mathrm{NH}_{3}$ concentration, harmful Eschericia coli and Clostridia spp. counts in the litter materials and reduced environmental pollution. The litter material of GLM supplemented $\left(\mathrm{T}_{1}, \mathrm{~T}_{2}\right.$ and $\left.\mathrm{T}_{3}\right)$ chicken showed significantly higher $(\mathrm{P}<0.05) \mathrm{CP}$ contents as compared to un-supplemented control. It can be concluded that properly sterilized litter material of GLM supplemented chicks act as cheaper alternative feedstuffs for ruminant's ration and reduce environmental pollution by lowering $\mathrm{NH}_{3}$ concentration, harmful E. coli and Clostridia counts in broiler litter material.
\end{abstract}

Keywords: Condensed tannins, Environmental pollution, Guava leaf meal, Litter material, Microbes, Nutrient composition

Million tons of poultry litter materials are produced annually worldwide. Broiler litter is a combination of accumulated excreta, feathers and bedding material which is a valuable source of nutrients such as nitrogen, phosphorus, sulphur, potassium and energy etc. The litter material is a valuable resource and can be used in many ways. It has varied nutrient composition from other agroindustrial by-products. Although, it is a good source of crude protein and minerals, while, energy values showed wide variation.

However, the poultry litter as a source of dangerous and unwanted pathogenic bacteria which could be resistant to antimicrobials and thus requires treatment before being fed. Although, its utilization as alternate feedstuffs, it needs to be processed properly and technology driven nutritional intervention to reduce its pathogenic microbial load (Elliott and Collins, 1982) and environmental pollution. Quality of litter is of great concern because it affects performance,

How to cite this article: Saharan, V., Pathak, A.K., Sharma, N., Sharma, R.K. and Kumar, H. (2020). Nutrient composition, metabolites and microbial counts in litter material of broiler chicken fed condensed tannins containing guava leaf meal supplemented diets: reduce environmental pollution and alternate feedstuffs for ruminants. J. Anim. Res., 10(3): 465470 .

Source of Support: None; Conflict of Interest: None

(क) 9 
health, carcass quality, and welfare of broilers and the farmers. Identifying suitable and affordable interventions is of particular importance in developing countries, as broiler production makes a significant contribution to the livelihoods of small-scale farmers. Now days properly sterilized litter material can also be one of the non protein nitrogenous (NPN)compounds as alternate feedstuffs for ruminant ration in many developing countries, as it is relatively cheaper source of nitrogen for ruminants (Tsadik et al., 2008).

Though, there is a growing concern about the environmental pollution caused by such an activity, especially air pollution and spread of disease causing pathogenic microorganism, as a result of huge amount of poultry excreta create nuisance and pollute the environment. If the proper guidelines/ mitigation strategies are not followed, the poultry litter generate undesirable odours, gases, suspension of particulate matter and dust, etc. (Meda et al., 2011; Copeland, 2014). The most significant gaseous pollutants in the poultry sheds are ammonia $\left(\mathrm{NH}_{3}\right)$, carbon dioxide $\left(\mathrm{CO}_{2}\right)$, carbon monoxide $(\mathrm{CO})$, methane $\left(\mathrm{CH}_{4}\right)$ and hydrogen sulphide $\left(\mathrm{H}_{2} \mathrm{~S}\right.$, Barrasa et al., 2012).

Besides, exposure, duration and concentration of pollutants inside poultry sheds may be associated with development of respiratory diseases in birds and humans (Naas, 2004). Particulate matter emitted from poultry sheds may contain pathogenic microorganisms, such as avian-influenza virus, Escherichia coli and Salmonela spp. etc. (Cambra-Lopez et al., 2010). Out of these gases, $\mathrm{NH}_{3}$ is the main pollutant affecting the health of birds and workers (Menegali et al., 2012). Complications due to $\mathrm{NH}_{3}$ exposure in poultry rearing have long been recognized. At higher concentration, it causes irritation of eyes and respiratory system and has a toxic effect over the physiological metabolism, leading to reduce feed intake, weight gain, and inefficient feed conversion and decline profit margin (Kilic and Yaslioglu, 2014). This negatively affects health status of human beings, poultry as well as of the surrounding ecosystem.

Dietary manipulation, composting and proper heat treatment are the practical methods to process the litter; although total nitrogen $(\mathrm{N})$ losses occurs mainly due to $\mathrm{NH}_{3}$ volatilization, that can reduce $\mathrm{N}$ value of litter as a fertilizer or alternative feedstuffs (Tiquia and Tamb, 2000). Here the dietary manipulation in the ration of experimental broiler chicken is the incorporation of condensed tannins (CT) containing guava leaf meal (GLM) with the hypothesis that the CT containing GLM showing potential role on pathogenic microorganism as well as on $\mathrm{NH}_{3}$ production.

Furthermore, improper management system and failures in computing all the balance of the released gases and pathogenic microorganisms can contribute to the underestimation of the polluting potential of poultry farms. Therefore, it is necessary to identify the means and type of environmental pollution associated with poultry production as well as how we can safely utilized litter material as alternative feedstuffs for feeding of ruminants and how we can set eco-friendly sustainable mitigation strategies to reduce the impacts caused by their emissions. Keeping all these points in view, the present study was planned to evaluate the impact of CT containing GLM supplementation in the diet of broiler chickens on nutrient composition, metabolites, $\mathrm{NH}_{3}$ levels and microbial load in broiler litter materials after completion experimental feeding trial of 42 days. Therefore, the present study warrant's investigation.

\section{MATERIALS AND METHODS}

The feeding schedule and experimental design of broiler chicken fed with and without Condensed tannins (CT) containing guava leaf meal (GLM) are presented in the table 1. Sixteen separate deep litter pen were prepared before the arrival of chicks. The rice husk was used as bedding materials for experimental chicks. Two hundred and forty chicks were randomly allocated into 4 dietary treatments, with 4 replicates of 15 chicks in each pen in a completely randomized block design (CRD). Chicks were fed basal diets formulated by incorporating feed ingredients procured from local market viz. crushed maize, soybean meal, rice bran, fish meal, meat cum bone meal, common salt, L-lysine Hcl, DL-methionine, di-calcium phosphate, lime stone powder, trace minerals and vitamin premix supplemented with guava leaf meal (GLM) at the rate of $1.5,2.5$ and 3.5 percent, respectively in $\mathrm{T}_{1}, \mathrm{~T}_{2}$ and $\mathrm{T}_{3}$ groups, while, chicks of $\mathrm{T}_{0}$ group fed only basal diet to fulfil the nutrient need as per ICAR (2013). All the chicks were provided adlib feed and water and followed standard management practices for rearing of chicks. 
Table 1: Experimental design and feeding schedule of experimental broiler chickens

\begin{tabular}{|c|c|c|c|c|c|c|c|c|c|c|c|c|c|c|c|}
\hline \multicolumn{16}{|c|}{240 day-old unsexed broiler chicks (Completely randomized block design for 42 days) } \\
\hline \multicolumn{4}{|c|}{ T0 } & \multicolumn{4}{|c|}{ T1 } & \multicolumn{4}{|c|}{ T2 } & \multicolumn{4}{|c|}{ T3 } \\
\hline \multicolumn{4}{|c|}{60 Chicks } & \multicolumn{4}{|c|}{60 Chicks } & \multicolumn{4}{|c|}{60 Chicks } & \multicolumn{4}{|c|}{60 Chicks } \\
\hline $\mathbf{R} 1$ & $\mathbf{R 2}$ & $\mathbf{R 3}$ & $\mathbf{R 4}$ & $\mathbf{R} 1$ & $\mathbf{R 2}$ & $\mathbf{R 3}$ & $\mathbf{R 4}$ & $\mathbf{R 1}$ & $\mathbf{R 2}$ & $\mathbf{R 3}$ & $\mathbf{R 4}$ & R1 & $\mathbf{R 2}$ & $\mathbf{R 3}$ & $\mathbf{R 4}$ \\
\hline 15 & 15 & 15 & 15 & 15 & 15 & 15 & 15 & 15 & 15 & 15 & 15 & 15 & 15 & 15 & 15 \\
\hline \multicolumn{4}{|c|}{ Basal diet } & \multicolumn{4}{|c|}{ Basal diet } & \multicolumn{4}{|c|}{ Basal diet } & \multicolumn{4}{|c|}{ Basal diet } \\
\hline \multicolumn{4}{|c|}{ GLM@0.0\% } & \multicolumn{4}{|c|}{ GLM@1.5\% } & \multicolumn{4}{|c|}{ GLM@2.5\% } & \multicolumn{4}{|c|}{ GLM @3.5\% } \\
\hline
\end{tabular}

A 3-phase (pre-starter, starter and finisher) feeding was followed for experimental broiler chicks as per ICAR (2013).

Table 2: Nutrient composition (on DM basis) of litter materials

\begin{tabular}{llllllll}
\hline \multirow{2}{*}{ Groups } & \multicolumn{7}{c}{ Nutrient composition (\%) } \\
\cline { 2 - 8 } & $\mathbf{C P}$ & $\mathbf{E E}$ & $\mathbf{C F}$ & $\mathbf{T A}$ & $\mathbf{A I A}$ & $\mathbf{C a}$ & $\mathbf{P}$ \\
\hline $\mathbf{T}_{\mathbf{0}}$ & $10.86^{\mathrm{c}}$ & $1.93^{\mathrm{a}}$ & $23.24^{\mathrm{a}}$ & $23.67^{\mathrm{a}}$ & $14.63^{\mathrm{a}}$ & 2.34 & 1.86 \\
$\mathbf{T}_{\mathbf{1}}$ & $9.21^{\mathrm{b}}$ & $2.24^{\mathrm{a}}$ & $23.99^{\mathrm{a}}$ & $23.81^{\mathrm{a}}$ & $15.02^{\mathrm{a}}$ & 2.56 & 1.44 \\
$\mathbf{T}_{\mathbf{2}}$ & $8.17^{\mathrm{a}}$ & $2.54^{\mathrm{ab}}$ & $25.67^{\mathrm{ab}}$ & $25.72^{\mathrm{ab}}$ & $16.88^{\mathrm{b}}$ & 2.77 & 1.39 \\
$\mathbf{T}_{3}$ & $8.06^{\mathrm{a}}$ & $2.69^{\mathrm{b}}$ & $28.08^{\mathrm{b}}$ & $28.93^{\mathrm{b}}$ & $19.22^{\mathrm{c}}$ & 2.83 & 1.01 \\
\hline
\end{tabular}

${ }^{a b c}$ Means with different superscript within a column differ significantly $(\mathrm{P}<0.05)$.

Litter samples were collected at the end of feeding trial of 42 days from 5 locations within each pen (4 equidistant from each corner and one central), thoroughly mixed and subsequently analyzed for $\mathrm{pH}$, moisture content, ammonia concentration, microbial counts and nutrient composition. The $\mathrm{pH}$ was recorded using digital $\mathrm{pH}$ meter after $30 \mathrm{~g}$ of macerated litter were added to $250 \mathrm{ml}$ of deionized water, agitated for $5 \mathrm{~min}$, and suspended for $30 \mathrm{~min}$. The $\mathrm{NH}_{3}$ (ppm) concentration in broiler litter material was determined by modified Chaney and Marbach (1962) method using two reagents viz. nitroprusside with phenol and hypochlorite with alkali.

Microbial counts in broiler excreta/ litter material were assessed by classical culture techniques using selective medium for specific group of microbes. Proximate analysis of experimental feeds and litter materials were performed according to AOAC (2012). Litter moisture was measured after drying for $24 \mathrm{~h}$ at $105^{\circ} \mathrm{C}$. Calcium and phosphorus contents were determined as per the methods described by Talpatra et al. (1941) and AOAC (2000), respectively. Results obtained were processed and analysed using SPSS 16.0 software. Significance was declared at $\mathrm{P}<0.05$ levels by using Duncan's multiple range test. Statistical procedures were done as per Snedecor and Cochran (2004).

\section{RESULTS AND DISCUSSION}

The chemical composition of the litter materials with and without GLM supplementation is shown in Table 2. Litter material of chicks fed GLM supplemented groups $\left(\mathrm{T}_{1}, \mathrm{~T}_{2}\right.$ and $\left.\mathrm{T}_{3}\right)$ showed lower $(\mathrm{P}<0.05)$ crude protein $(\mathrm{CP})$ contents as compared to litter material of un-supplemented group $\left(\mathrm{T}_{0}\right)$. Present results are in harmony with the findings of Min et al. (2015) who observed that increase in uric acid is consistent with $\mathrm{NH}_{3}$ reduction in poultry litter treated with pine bark tanninthat's why increased CP contents in litter materials. Higher CP contents and lower $\mathrm{NH}_{3}$ concentrations in the litter materials of CT containing GLM supplemented groups might be related with the $\mathrm{NH}_{3}$ reduction in litter materials of supplemented groups. However, other proximate principles viz. ether extract, crude fibre, total ash and acid insoluble ash were found to be highest in the litter materials of $\mathrm{T}_{3}$ group followed by $\mathrm{T}_{2}$, $\mathrm{T}_{1}$ and the lowest in the litter materials of $\mathrm{T}_{0}$ group, while, the calcium and phosphorus contents of litter material did not differ significantly irrespective of groups. 
Table 3: Effect of CT containing GLM on litter metabolites and bacterial counts of broiler chickens after completion of feeding trial of 42 days

\begin{tabular}{|c|c|c|c|c|c|}
\hline \multirow{2}{*}{ Bacterial species } & \multicolumn{4}{|c|}{ Groups } & \multirow{2}{*}{ - P valu } \\
\hline & $\mathbf{T}_{0}$ & $\mathrm{~T}_{1}$ & $\mathbf{T}_{2}$ & $\mathbf{T}_{3}$ & \\
\hline \multicolumn{6}{|l|}{ Litter metabolites } \\
\hline Moisture (\%) & $18.28^{c} \pm 0.18$ & $17.22^{\mathrm{c}} \pm 0.08$ & $15.67^{\mathrm{b}} \pm 0.36$ & $13.88^{\mathrm{a}} \pm 0.51$ & 0.000 \\
\hline $\mathrm{pH}$ & $7.69^{c} \pm 0.13$ & $7.52^{\mathrm{bc}} \pm 0.07$ & $7.28^{\mathrm{ab}} \pm 0.09$ & $7.13^{\mathrm{a}} \pm 0.06$ & 0.012 \\
\hline $\mathrm{NH}_{3}(\mathrm{ppm})$ & $71^{\mathrm{d}} \pm 9.77$ & $66^{c} \pm 2.85$ & $61^{\mathrm{b}} \pm 6.08$ & $49^{\mathrm{a}} \pm 2.52$ & 0.016 \\
\hline \multicolumn{6}{|c|}{ Bacterial counts $(\log 10 \mathrm{CFU} / \mathrm{g}$ of litter material) } \\
\hline Clostridium spp. & $8.84^{\mathrm{b}} \pm 0.16$ & $8.81^{\mathrm{b}} \pm 0.23$ & $8.27^{a} \pm 0.13$ & $8.12^{\mathrm{a}} \pm 0.08$ & 0.026 \\
\hline Eschericia coli & $9.96^{\mathrm{b}} \pm 0.23$ & $9.83^{b} \pm 0.09$ & $9.23^{\mathrm{a}} \pm 0.11$ & $9.06^{\mathrm{a}} \pm 0.06$ & 0.004 \\
\hline
\end{tabular}

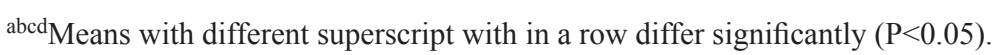

The litter metabolites (moisture, $\mathrm{pH}$ and $\mathrm{NH}_{3}$ concentration) and microbial loads (E. coli and Clostridia) of broiler chicken with and without GLM supplementation are presented in the table 3. Litter materials of chicks fed GLM supplemented diets (@ 1.5, 2.5 and 3.5) had decreased $(\mathrm{P}<0.05) \mathrm{pH}, \mathrm{NH}_{3}$ concentration, E. coli and Clostridia spp. counts than that of un-supplemented control. As the level of GLM in the diet increased $\mathrm{pH}, \mathrm{NH}_{3}$ concentration, E. coli and Clostridia spp. counts decreased significantly $(\mathrm{P}<0.05)$ in the litter materials. However, the litter materials of chicks fed GLM supplemented diet had significantly $(\mathrm{P}<0.05)$ lower moisture contents. The higher litter $\mathrm{pH}$, moisture and temperature are the important factors that affect $\mathrm{NH}_{3}$ concentration (Coufal et al., 2006).

Lower moisture contents, $\mathrm{pH}$ and $\mathrm{NH}_{3}$ concentrations in the litter materials of supplemented groups as compared to un-supplemented control might be due to anti-microbial activity of CT in GLM, which lowered litter $\mathrm{pH}$ and ultimately reduce $\mathrm{NH}_{3}$ concentration. An association between litter moisture and $\mathrm{NH}_{3}$ emission was also observed by Liu et al. (2007) in their experimental study. The presence of CT in the excreta of GLM supplemented chickens might have contributed to the reduction of substrate for microbial growth, and thus the formation of $\mathrm{NH}_{3}$ (Pathak et al., 2017). Previous workers reported that low to moderate level of CT from tree leaf meal mixture (LMM) supplementation improved gastrointestinal $\mathrm{N}$ balance, microbial protein (MP) synthesis but had negative impact on gastrointestinal parasites (Haemonchus contortus) of lambs, sheep and goats (Pathak et al. 2015, 2017; Khan et al., 2019 and Singh et al., 2016), whereas
Min et al. (2014) had observed changes in bacterial and methanogenic populations in the gastrointestinal tract (GIT) of goats supplemented with CT. Manipulations of $\mathrm{NH}_{3}$ conversion from uric acid, reduces $\mathrm{NH}_{3}$ volatilisation and $\mathrm{N}$ loses from poultry litter.

Furthermore, conversion of uric acid to $\mathrm{NH}_{3}$ is attributed to microorganisms that use uric acid as $\mathrm{N}$ source (Kim et al., 2009). CT also reduces $\mathrm{NH}_{3}$ release in rumen through reduction of protein degraded by microorganisms due to binding of $\mathrm{CT}$ with proteins making a complex of CT-protein that is resistant to microbial enzymes in rumen (Naumann et al., 2017; Pathak et al., 2015, 2017). Similarly, Min et al. (2012) reported decline protein degradation with subsequent reduction in $\mathrm{NH}_{3}$ production in the rumen of goats. $\mathrm{NH}_{3}$ is related to environmental pollution and interrelated to the health of human, poultry and environment. It is an added advantage if litter material has a low $\mathrm{pH}$, because the conversion of excretory uric acid into $\mathrm{NH}_{3}$ is decreased at acidic $\mathrm{pH}$ (Moore et al., 1995), while, as the $\mathrm{pH}$ rises above 7 , the ionized $\mathrm{NH}_{3}$ shifts to un-ionized form and thus more $\mathrm{NH}_{3}$ is available for volatilization (Elliott and Collins, 1982). Therefore, properly processed litter materials free from pathogens were used as feedstuffs for feeding of ruminants in many developing countries (Mavimbela et al., 1997; Tsadik et al., 2008; Akinfala and Komolafe, 2011) as it was relatively cheap NPN source of $\mathrm{N}$ for ruminants (Van Ryssen, 2001). The CT containing GLM supplementation in broiler diets may be an attractive natural modification to preserve $\mathrm{CP}$ contents of alternative feedstuff by reducing $\mathrm{NH}_{3}$ production side by side reducing E. coli and Clostridia 
counts by breaking the chain of pathogenic microorganism spread in the ecosystem.

\section{CONCLUSION}

It can be concluded that dietary supplementation of condensed tannins containing guava leaf meal in broiler chickens reduced $\mathrm{NH}_{3}$ concentration and pathogenic $E$. coli and Clostridia counts in broiler litter material. Properly processed and sterilized litter material act as cheaper alternative feedstuffs, considered as a safe, environmentfriendly and sustainable approach to save nutrients for better ruminant production practices and reduce environmental pollution. Further research is needed to know the exact mechanism by which CT containing GLM target on specific group of microorganism's reduction, and their specific metabolites generated in the gastrointestinal tract of broiler chicken which shows suppression of $\mathrm{NH}_{3}$ production and mitigate environmental pollution is warranted.

\section{REFERENCES}

Akinfala, E.O. and Komolafe, O.B. 2011. Evaluation of different processing methods on the nutrient composition of broiler litter and its utilization by weaner pigs in the tropics. Livest. Res. Rural Dev., 23: 228 (online version).

AOAC. 2000. Official methods of analysis, $16^{\text {th }}$ edn. Association of Official Analytical Chemists. Washington, DC.

AOAC. 2012. Official methods of analysis (19 ${ }^{\text {th }}$ ed.). Association of Official Analytical Chemists. Washington, DC.

Barrasa, M., Lamosa, S., Fernandez, M.D. and Fernandez, E. 2012. Occupational exposure to carbon dioxide, ammonia and hydrogen sulphide on livestock farms in north-west Spain. Ann. Agric. Environ. Med., 19(1): 17-24.

Cambra-López, M., Aarnink, A.J.A., Zhao, Y., Calvetm, S. and Tores, A.G. 2010. Airborne particulate matter from livestock production systems: A review of an air pollution problem. Environ. Poll., 158: 1-17.

Chaney, A.L. and Marbach, E.P. 1962. Modified reagents for determination of urea and ammonia. Clin. Chem., 8: 130-132.

Copeland, C. 2014. Air quality issues and animal agriculture: A primer. Congressional Research Service, Informing the legislative debate since, pp. 34 .

Coufal, C.D., Chavez, C., Niemeyer, P.R. and Carey, J.B. 2006. Measurement of broiler litter production rates and nutrient content using recycled litter. Poult. Sci., 85: 398-403.
Elliott, H.A. and Collins, N.E. 1982. Factors affecting ammonia release in broiler litter. Trans. ASAE, 25: 413-424.

ICAR, 2013. Nutrient Requirement of Animals-Poultry (ICARNIANP), Indian Council of Agricultural Research, New Delhi.

Khan, M., Pathak, A.K. and Singh, S. 2019. Nutrient metabolism, blood Indices and Immunity in Haemonchus contortus infected goats fed condensed tannins enriched densified complete feed blocks. Anim. Nutr. Feed Technol., 19: 417430.

Kilic, I. and Yaslioglu, E. 2014. Ammonia and carbon dioxide concentrations in a layerhouse. Asian-Aust. J. Anim. Sci., 27(8): 1211-1218.

Kim, W.K., Weeks, L.J., Anderson, R.C., Nisbet, D.J., Dunkley, K. and Ricke, S.C. 2009. Effects of nitro-compounds on uric acid-utilizing microorganisms, nitrogen retention, and microbial community in laying hen manure. J. Environ. Sci. Health Part B., 44(4): 403-406.

Liu, Z., Wang, L., Beasley, D. and Oviedo, E. 2007. Effect of moisture content on ammonia emissions from broiler litter: A laboratory study. J. Atmos. Chem., 58: 41-53.

Mavimbela, D.T., Van Ryssen, J.B.J. and Last, R. 1997. The effect of high broiler litter diets as survival ration on the health of sheep. J. S. Afr. Vet. Assoc., 68: 121-124.

Meda, B., Hassouna, M., Aubert, C., Robin, P. and Dourmad, J.Y. 2011. Influence of rearing conditions and manure management practices on ammonia and greenhouse gas emissions from poultry houses. World Poult. Sci. J., 67: 441-456.

Menegali, I., Tinôco, I.F.F., Zolnier, S., Carvalho, C.C.S. and Guimarães, M.C.C. 2012. Influence of different systems of minimum ventilation on air quality in broiler houses. Eng. Agric., 32(6): 1024-1033.

Min, B.R., Solaiman, S., Gurung, N., Behrends, J., Eun, J.S. and Taha, E. 2012. Effects of pine bark supplementation on performance, rumen fermentation, and carcass characteristics of Kiko crossbred male goats. J. Anim. Sci., 90(10): 35563567.

Min, B.R., Solaiman, S., Shange, R. and Eun, J.S. 2014. Gastrointestinal bacterial and methanogenicarchaea diversity dynamics associated with condensed tannin-containing pine bark diet in goats using $16 \mathrm{~S}$ rDNA amplicon pyro sequencing. Int. J. Microbiol., 2014:141909.

Moore, P.A., Daniel, T.C., Sharpley, A.N. and Wood, C.W. 1995. Poultry manure management: Environmentally sound options. J. Soil Water Conserv., 50: 321-327.

Naas, I.A. 2004. Categorias de poluentes do ar. In: Workshop qualidade do areminstalaçõeszootécnicas. Viçosa, MG. CDROM. 
Naumann, H.D., Tedeschi, L.O., Zeller, W.E. and Huntley, N.F. 2017. The role of condensed tannins in ruminant animal production: advances, limitations and future directions. Rev. Bra. Zoot., 46(12): 929-949.

Pathak, A.K., Dutta, N. and Sharma, K. 2015. Influence of condensed tannins supplementation through leaf meal mixture on Urinary excretion of purine derivatives, microbial protein synthesis and performance of Haemonchus contortus infected sheep. J. Anim. Res., 5(4): 719-727.

Pathak, A.K., Dutta, N., Pattanaik, A.K., Chaturvedi, V.B. and Sharma, K. 2017. Effect of condensed tannins from Ficus infectoria and Psidium guajava leaf meal mixture on nutrient metabolism, methane emission and performance of lambs. Asian-Aust. J. Anim. Sci., 30(12): 1702-1710.

Singh, S., Pathak, A.K., Khan, Muzaffar and Sharma, R.K. 2016. Effect of tanniferous leaf meal mixture based multi nutrient blocks on nutrient utilization and biochemical profile of Haemonchus contortus infected goats. Indian J. Anim. Res., 50(5): 725-732.
Snedecor, G.W. and Cochran, W.G. 2004. Statistical methods. $8^{\text {th }}$ Edn., East West Press Pvt. Ltd., New Delhi.

Talpatra, S.K., Ray, S.C. and Sen, K.C. 1940. Estimation of phosphorus, chlorine, calcium, magnesium, sodium and potassium in foodstuffs. Indian J. Vet. Sci. Anim. Husb., 10: 243-258.

Tiquia, S.T. and Tamb, N.F.Y. 2000. Fate of nitrogen during composting of chicken litter. Environ. Poll., 110(3): 535-541.

Tsadik, A.G., Tamir, B. and Melaku, S. 2008. Inclusion of different proportions of poultry litter in the rations of yearling Hararghe Highland goats. Livest. Res. Rural Dev., 20: 48 (online version).

Van Ryssen, J.B.J. 2001. Poultry litter as a feedstuff for ruminants: A South African scene. SA-Anim. Sci., 2: Accessed Apr. 2012. http://www.sasas.co.za/Popular/ Popular.html. 